\title{
A CIRCULAR SHAPED MULTIBAND SEMI-COMPOUND RECONFIGURABLE ANTENNA WITH FREQUENCY AND PATTERN DIVERSITY FOR WIRELESS APPLICATIONS
}

Pandurangaiah Y. - Professor, Head of the Department of Electronics and Communication Engineering, Vardhaman College of Engineering, Hyderabad, Telangana, India.

Satyanarayana R.V.S. - Dr., Professor of the Department of Electronics and Communication Engineering, Sri Venkateswara University, Tirupati, India.

\section{ABSTRACT}

Context. The problem of achieving multi band functionality and two or more reconfiguration capabilities by using a single antenna for diversified Wireless communication applications. The objective of the work is to model a prototype that combines the above functionalities.

Objective. The major goal of the work is to produce a very efficient and compact antenna satisfying all the requirements for wireless applications combining semi compound reconfigurability and multi-band functionality for Wireless communication applications.

Method. This paper reports design and investigations on a planar multi-band frequency- and pattern-circular shaped reconfigurable antenna by the use of PIN diodes. It consists of symmetrically placed, seven PIN diodes on each half of the circle cutting the longitudinal axis. By changing the controlled activation of the slots placed on a circular disk which is fed by Coplanar Waveguide feed, the required reconfiguration mechanism is achieved. The antenna can be operated in 8 different modes by the use of 15 PIN diodes. A beam shape pattern reconfigurability is achieved by operating the antenna in all the modes. The basic antenna is a circular disk without slots and is designed to operate at $2.4 \mathrm{GHz}$. Frequency reconfigurability is achieved by changing the overall electrical length of the slot by activating the switches in appropriate positions in different operating modes. Pattern reconfigurability is achieved by maintaining the same overall electrical length in each operating mode but changing the switch positions orient in a particular direction in each half of the circle.

Results. The model has been developed and investigative simulations were carried out using Ansys HFSS.

Conclusions. The proposed antenna resonates at three frequencies $2.2 \mathrm{GHz}, 4.98 \mathrm{GHz}$ and $5.72 \mathrm{GHz}$ when operated in pattern reconfigurability mode. A simultaneous frequency reconfigurability along with pattern is achieved with more $($ at $6.2 \mathrm{GHz}, 8.2 \mathrm{GHz}$ and $9 \mathrm{GHz}$ ) or less number of new frequency bands (at $7.1 \mathrm{GHz}$ ) than pattern reconfiguration mode. The area of the antenna occupied is 40 $\mathrm{X} 60 \mathrm{~mm}^{2}$. An acceptable gain is obtained in all of the operating modes. The prototype of the designed antenna has been developed and the simulation results have been verified experimentally.

KEYWORDS: Frequency diversity, Pattern diversity, Reconfigurable antennas, PIN diodes, Circular patch, RF switch, Gain.

\author{
ABBREVIATIONS \\ CPW is a Coplanar Waveguide; \\ MIMO is a Multi-Input-Multi-Output; \\ EM is an Electromagnetic; \\ PIN is a p-type-Intrinsic-n-type; \\ HFSS is a High Frequency Structure Simulator; \\ FEM is a Finite Element Method; \\ Wi-Fi is a Wireless Fidelity; \\ Wi-MAX is a Worldwide Interoperability for Micro- \\ wave Access; \\ WLAN is a Wireless Local Area Network; \\ IEEE is an Institute of Electrical and Electronics En-
} gineers.

\author{
$\theta$ is an Elevation angle; \\ $\varphi$ is an Azimuth angle;

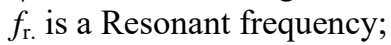 \\ $\varepsilon_{\mathrm{r}}$ is a Relative Permittivity; \\ $\mu_{\mathrm{r}}$ is a Relative Permeability; \\ $a_{e}$ is an effective radius.
}

NOMENCLATURE

\section{INTRODUCTION}

Today's modern wireless and electronic communication systems require multifunctional, compact, smart an- tennas that can adapt to varying system requirements. These requirements are not met by fixed performance antennas whose fundamental properties like frequency, polarization and pattern characteristics are fixed. In this context there are two types of antennas.

1) Reconfigurable antennas which have the ability to dynamically meet such adaptable service requirements [1]. Several antennas have been reported which have single reconfiguration capability i.e., either in frequency [2], polarization [3] or pattern [4] accordingly the antennas are frequency, polarization and pattern reconfigurable antennas.

2) Multiband antennas that can meet the challenges like miniaturize circuit dimension while maintaining transmission performance, including multiple operation bands, low cost, high efficiency, wide bandwidth and acceptable gain, are proved to be common solutions. Recently there are many developments made in the designing the antennas with two or more reconfiguration capabilities; combining frequency - polarization, polarization - pattern, frequency - pattern reconfigurations called as compound reconfigurable antennas.

The reconfigurable antennas and multi band antennas offer a good solution to meet the fixed performance antennas problem. 
The major object of study to design an antenna combining multi-band functionality and two function reconfigurability in order to produce a very efficient and compact antenna satisfying all the requirements.

The subject of study is reconfiguration method deploying slots and PIN diodes for changing the electrical length and the surface current distributions that in turn produce the change in frequency, polarization or pattern.

The purpose of the work is to make use of a single antenna which is compact in size serving multiple requirements for major wireless service applications.

\section{PROBLEM STATEMENT}

An antenna with slotted aperture has to be used for obtaining multi-band characteristics. Also, by adding or removing part of the antenna length through means of PIN diodes, the effective length of the antenna can be changed and hence it's operating frequency. By changing the course of direction of flow of current using PIN switches there by intentionally modifying the spherical distribution of radiation, pattern reconfiguration is achieved.

\section{REVIEW OF THE LITERATURE}

A folded slot monopole antenna with quad band [5], a meandered folded monopole antenna with extended staircase and F-shaped arms [6] that operates at five frequency bands have been reported. Antennas combining two or more diversity features support individual selection of frequency and radiation characteristics at varying degrees [7-8]. Moreover, pattern reconfiguration has received much attention because of their diversity functions in radiation patterns that enhances the performance of wireless communication systems. One of the techniques to achieve diversity in pattern is to reconfigure the beam shape which can be used to improve the system capacity and quality of the link [9-11].

Very less work is done in the area of multi-band reconfigurable antennas [12-14]. In [12], the authors developed a wideband and multi band frequency reconfigurable antenna using PIN and varactor diodes which are regulated by integrated microcontroller controlled embedded biasing network. In [13], the authors demonstrated by placing four identical slots on the radiating patch and two slots on the ground structure, the antenna can radiate at 10 narrow frequency bands. In [14], a reconfigurable multiband CPW fed planar patch MIMO array antenna operating in three operating modes is proposed. In [15], an extended U-slot patch antenna with shutter shaped slots on the ground plane is designed for multiband polarization reconfigurability. The authors in [16], presented a single feed annular ring slot reconfigurable antenna using five PIN diodes to produce frequency and polarization diversities.

\section{MATERIALS AND METHODS}

The geometrical configuration of the proposed multiband frequency and pattern reconfigurable antenna is shown in Fig. 1. The antenna is designed on low cost FR4-Epoxy material with dielectric constant $\varepsilon_{\mathrm{r}}=4.4$, loss tangent $\tan \delta=0.02$ and thickness $\mathrm{t}=1.6 \mathrm{~mm}$. The area occupied by the antenna is $40 \times 60 \mathrm{~mm}^{2}$.

The main structure of the antenna consists of a circular disk which is designed to operate at $2.4 \mathrm{GHz}$ following the design guidelines given by (1), (2) [17]:

$$
\begin{gathered}
f_{r}=\frac{1.84118 \mathrm{c}}{2 \pi \mathrm{ae} \sqrt{\varepsilon r \mu \mathrm{r}}}, \\
\mathrm{a}_{\mathrm{e}}=\mathrm{a} \sqrt{1+\frac{2 h}{\pi a \varepsilon_{r}}\left\{\ln \left(\frac{\pi \mathrm{a}}{2 \mathrm{~h}}\right)+1.7723\right\}} .
\end{gathered}
$$

Where $\mu_{r}=1$ in this case, 'c' is the velocity of the light, ' $a$ ' is the actual radius of the circular patch and ' $t$ ' is the thickness of the substrate. The actual radius ' $a$ ' calculated from the above formula of the circular patch which resonates at $2.4 \mathrm{GHz}$ is $24 \mathrm{~mm}$ but due to introduction of rectangular slots at the edges, the radius is reduced by 1.7 times $(\approx 14 \mathrm{~mm})$. The other dimensions of the antenna are listed in Table 1. A coplanar waveguide feeding is used to excite the antenna because of it's many advantages over the conventional microstrip line, such as simple fabrication, wide impedance bandwidth, easy surface mounting for series and shunt devices, and low radiation [18].

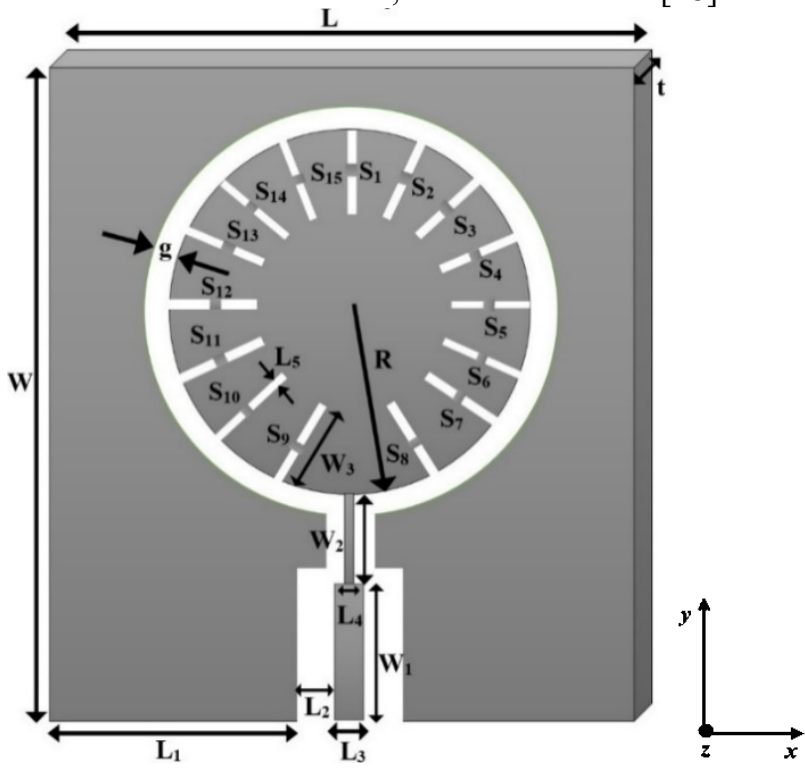

Figure 1 - Geometrical layout of the proposed multi-band Frequency and Pattern Reconfigurable Antenna

A strip of length $\mathrm{W}_{2}$ and width $\mathrm{L}_{4}$ is used as impedance matching stub between the feed and the circular patch to improve the radiation characteristics of the antenna. In order to have multi band operation, slotting technique is employed in the design. Rectangular slots of equal length $7 \mathrm{~mm}$ and width $1 \mathrm{~mm}$ are placed at every $22.5^{\circ}$ angle position starting from feed point on the circular disk as shown in Fig. 1. In order to achieve reconfigurability, 15 switches $\left(S_{1}-S_{15}\right)$ as shown in Fig. 1 were placed at center position on each slot connecting them. The various operating modes are shown in Table 2. PIN diodes are employed to have switching mechanism. 
At RF frequencies, PIN diodes behave as a variable resistor, with equivalent circuit model for ON/OFF states, as shown in Fig. 2. Both the ON and OFF states have a package inductance $\mathrm{L}_{\mathrm{S}}$. The equivalent circuit for the $\mathrm{ON}$ state (forward biased) as shown in Fig. 2a has a low resistance $\mathrm{R}_{\mathrm{S}}$ which contributes to insertion loss. The equivalent circuit for the OFF state (reverse biased) as shown in Fig. $2 b$ has parallel combination of reverse bias resistance $\mathrm{R}_{\mathrm{P}}$ and total capacitance $\mathrm{C}_{\mathrm{T}}$, which contributes to the isolation. The biasing circuit to make the switches active and inactive is shown in Fig. 2c.

Table 1 - Optimized Geometrical Parameters of the proposed Reconfigurable Antenna

\begin{tabular}{|c|c|c|c|}
\hline Parameter & $\begin{array}{c}\text { Dimension } \\
(\mathrm{mm})\end{array}$ & Parameter & $\begin{array}{c}\text { Dimension } \\
(\mathrm{mm})\end{array}$ \\
\hline $\mathrm{L}$ & 40 & $\mathrm{~L}_{3}$ & 3.0589 \\
\hline $\mathrm{W}$ & 60 & $\mathrm{~L}_{4}$ & 0.5345 \\
\hline $\mathrm{t}$ & 1.6 & $\mathrm{~L}_{5}$ & 1.0 \\
\hline $\mathrm{R}$ & 14 & $\mathrm{~W}_{1}$ & 15.8071 \\
\hline $\mathrm{g}$ & 2.0 & $\mathrm{~W}_{2}$ & 8.3554 \\
\hline $\mathrm{L}_{1}$ & 16.4706 & $\mathrm{~W}_{3}$ & 7.0 \\
\hline $\mathrm{L}_{2}$ & 2.0 & $\varepsilon_{\mathrm{r}}$ & 4.4 \\
\hline
\end{tabular}

Table 2 - Different Switch configurations of the proposed Reconfigurable Antenna

\begin{tabular}{|c|c|c|c|}
\hline Configuration & $\begin{array}{l}\text { Switch } \\
\text { Position }\end{array}$ & $\begin{array}{l}\text { Switch } \\
\text { status }\end{array}$ & $\begin{array}{l}\text { Type of Recon- } \\
\text { figurability }\end{array}$ \\
\hline $\mathrm{C}_{1}$ & $\mathrm{~S}_{1}-\mathrm{S}_{15}$ & OFF & $\begin{array}{l}\text { Frequency and } \\
\text { Pattern }\end{array}$ \\
\hline $\mathrm{C}_{2}$ & $\mathrm{~S}_{1}-\mathrm{S}_{15}$ & $\mathrm{ON}$ & $\begin{array}{c}\text { Frequency and } \\
\text { Pattern }\end{array}$ \\
\hline $\mathrm{C}_{3}$ & $\mathrm{~S}_{7}, \mathrm{~S}_{8}, \mathrm{~S}_{14}, \mathrm{~S}_{15}$ & $\mathrm{ON}$ & Pattern \\
\hline $\mathrm{C}_{4}$ & $\mathrm{~S}_{2}, \mathrm{~S}_{3}, \mathrm{~S}_{9}, \mathrm{~S}_{10}$ & $\mathrm{ON}$ & Pattern \\
\hline $\mathrm{C}_{5}$ & $\mathrm{~S}_{1}, \mathrm{~S}_{5}, \mathrm{~S}_{12}$ & OFF & $\begin{array}{c}\text { Frequency and } \\
\text { Pattern }\end{array}$ \\
\hline $\mathrm{C}_{6}$ & $\mathrm{~S}_{3}, \mathrm{~S}_{7}, \mathrm{~S}_{10}, \mathrm{~S}_{14}$ & OFF & $\begin{array}{c}\text { Frequency and } \\
\text { Pattern }\end{array}$ \\
\hline \multirow{3}{*}{$\mathrm{C}_{7}$} & $\mathrm{~S}_{1}, \mathrm{~S}_{3}$ & OFF & \multirow{3}{*}{$\begin{array}{c}\text { Frequency and } \\
\text { Pattern }\end{array}$} \\
\hline & $\mathrm{S}_{5}, \mathrm{~S}_{7}$ & OFF & \\
\hline & $\mathrm{S}_{10}, \mathrm{~S}_{12}, \mathrm{~S}_{14}$ & OFF & \\
\hline \multirow{2}{*}{$\mathrm{C}_{8}$} & $\mathrm{~S}_{2}, \mathrm{~S}_{4}, \mathrm{~S}_{6}, \mathrm{~S}_{8}$ & $\mathrm{ON}$ & \multirow{2}{*}{$\begin{array}{c}\text { Frequency and } \\
\text { Pattern }\end{array}$} \\
\hline & $\mathrm{S}_{9}, \mathrm{~S}_{11}, \mathrm{~S}_{13}, \mathrm{~S}_{15}$ & $\mathrm{ON}$ & \\
\hline
\end{tabular}

In this design, the PIN diode is modelled in HFSS using two series lumped RLC boundary conditions, as shown in Fig. 3, where the first part of RLC boundary is $\mathrm{L}$ and second is either $\mathrm{R}_{\mathrm{S}}$ for the $\mathrm{ON}$ state or a parallel combination of $R_{P}$ and $C_{T}$ for the OFF state. This way of modelling is used to achieve robustness in terms of reconfiguration between different frequency bands.

In this diode model, the ON state lumped parameter values are chosen to be $\mathrm{R}_{\mathrm{S}}=1 \Omega, \mathrm{L}_{\mathrm{S}}=0.7 \mathrm{nH}$ and $\mathrm{OFF}$ state values are chosen as $\mathrm{R}_{\mathrm{P}}=2 \mathrm{k} \Omega, \mathrm{C}_{\mathrm{T}}=0.3 \mathrm{pF}$. These values are chosen according to the datasheet of the PIN diode SMP1340-079LF from Skyworks Solutions.

When all the switches are OFF, the antenna is set to operate in $\mathrm{C}_{1}$, the antenna resonates at four fundamental frequencies namely $2.3 \mathrm{GHz}, 4.9 \mathrm{GHz}, 5.28 \mathrm{GHz}$ and $5.55 \mathrm{GHz}$ and when all the switches were made $\mathrm{ON}$ in configuration $\mathrm{C}_{2}$, the antenna resonates at $2.4 \mathrm{GHz}$,
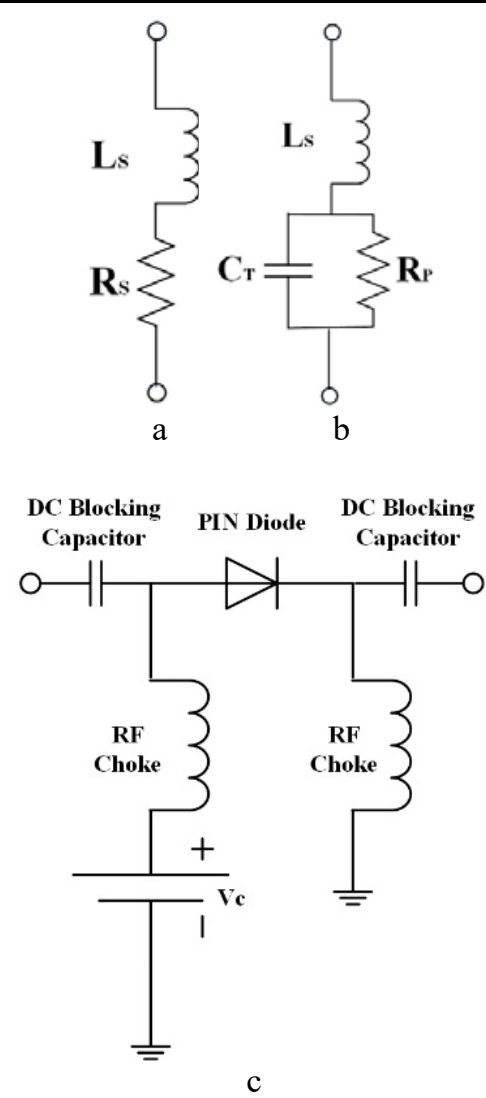

Figure 2 - PIN diode equivalent circuit (a) ON state (b) OFF state. (c) Bias Circuit

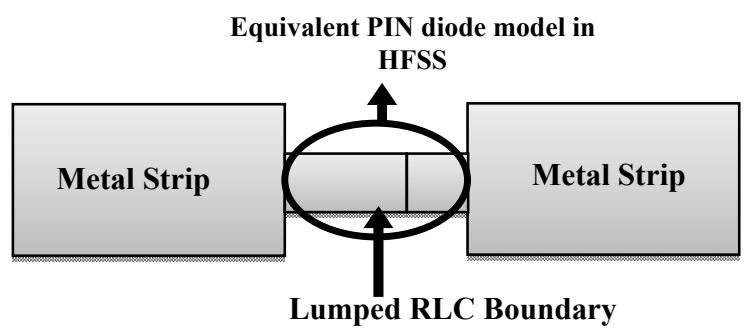

Figure 3 - Modelling of PIN diode in HFSS

4.6GHz, $6.2 \mathrm{GHz}, 8.2 \mathrm{GHz}$ and $9.0 \mathrm{GHz}$. It is observed that there is change in the radiation pattern in elevation plane by $30^{\circ}$ at first fundamental frequency. Hence the antenna is said to have simultaneous frequency and pattern reconfiguration when operated in $\mathrm{C}_{1}$ and $\mathrm{C}_{2}$. In $\mathrm{C}_{3}$, when the switches at $22.5^{\circ}$ and $45^{\circ}$ position of the bottom right half of circular disk $\left(\mathrm{S}_{7}, \mathrm{~S}_{8}\right)$ and top left half of circular disk $\left(\mathrm{S}_{14}, \mathrm{~S}_{15}\right)$ are activated as shown in Fig. 4 a, the antenna exhibits triple band resonating at $2.3 \mathrm{GHz}, 4.29 \mathrm{GHz}$ and 5.5GHz. In $\mathrm{C}_{4}$, when the switches in opposite direction to that of $\mathrm{C}_{3}$ i.e., $\left(\mathrm{S}_{2}, \mathrm{~S}_{3}\right)$ and $\left(\mathrm{S}_{9}, \mathrm{~S}_{10}\right)$ are activated as shown in Fig. $4 \mathrm{~b}$, the antenna resonates at the similar frequencies but there is a change in radiation pattern direction in elevation plane. Hence the antenna is said to exhibit multiband pattern reconfigurability when it is reconfigured from $\mathrm{C}_{3}$ to $\mathrm{C}_{4}$. Likewise, in $\mathrm{C}_{5}$, when the switches at $22.5^{0}$ and $45^{\circ}$ positions are turned to $\mathrm{ON}$ state as shown in Fig. $4 \mathrm{c}$, it operates at 5 bands and in $\mathrm{C}_{6}$, the switches at $22.5^{\circ}$ and $90^{\circ}$ positions are activated to make the antenna 
change its radiation pattern when operated from $\mathrm{C}_{5}$ to $\mathrm{C}_{6}$. This is shown in Fig. 4d. In this configuration, the antenna operates at only two bands centred at $2.34 \mathrm{GHz}$ and $7.11 \mathrm{GHz}$. Hence the antenna can able to switch between frequency and pattern when it is reconfigured from $\mathrm{C}_{5}$ to $\mathrm{C}_{6}$. When it is reconfigured to $\mathrm{C}_{7}$ i.e., when switches at $45^{\circ}$ and $90^{\circ}$ positions were made $\mathrm{ON}$ as shown in Fig. $4 \mathrm{e}$, it is observed that there is a change in number of bands and the frequencies with change in radiation pattern. It operates at $2.3 \mathrm{GHz}, 4.2 \mathrm{GHz}$ and $5.05 \mathrm{GHz}$ with good return loss at $2.3 \mathrm{GHz}$ compared to other frequencies. Hence it shows simultaneous frequency and pattern reconfiguration when it is reconfigured from any of the above configurations. Alternatively, when switches at all $22.5^{\circ}$ positions were made $\mathrm{ON}$ as in Fig. $4 \mathrm{f}$, there is a shift in the second and third frequency bands when compared with $\mathrm{C}_{7}$ to $5 \mathrm{GHz}$ and $7.1 \mathrm{GHz}$ respectively having first resonant mode unchanged. The pattern shape changes from directional to dipole like pattern when antenna is reconfigured from $\mathrm{C}_{7}$ to $\mathrm{C}_{8}$.
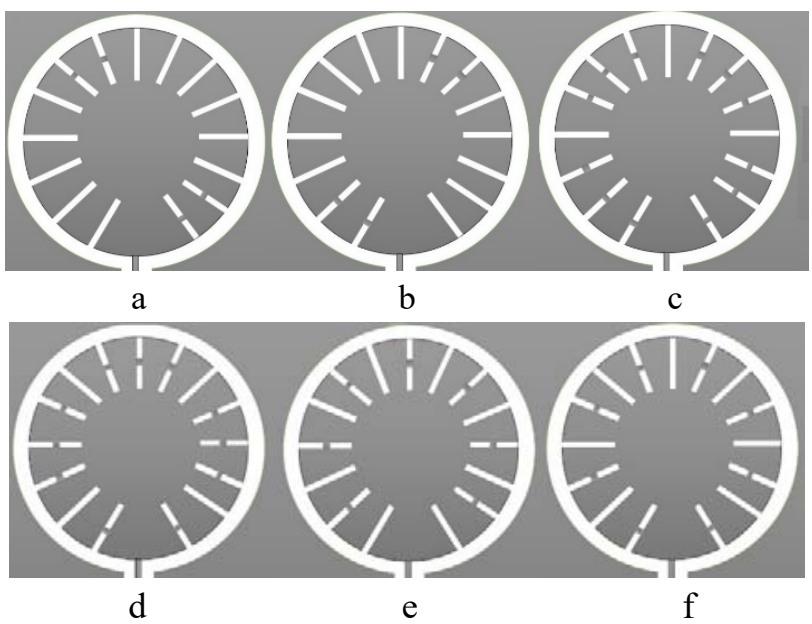

Figure 4 - Antenna operating in $\mathrm{C}_{3}, \mathrm{C}_{4}, \mathrm{C}_{5}, \mathrm{C}_{6}, \mathrm{C}_{7}$ and $\mathrm{C}_{8}$ configurations

\section{EXPERIMENTS}

The numerical optimizations have been performed to achieve the desired resonant frequencies using commercial EM simulator HFSS Version 17.0 which is based on Finite Element Method (FEM) numerical technique.

It has been observed that frequency and pattern switching of the proposed multi band reconfigurable antenna is obtained by positioning PIN diodes as switch on the slot. The proposed antenna is reconfiguring simultaneously in frequency and pattern when operated in $\left(\mathrm{C}_{1}\right.$, $\left.\mathrm{C}_{2}\right),\left(\mathrm{C}_{5}, \mathrm{C}_{6}\right)$ and $\left(\mathrm{C}_{7}, \mathrm{C}_{8}\right)$ configurations. The frequency is reconfigured in $\mathrm{S}, \mathrm{C}$ and $\mathrm{X}$ frequency bands with resonant frequencies from 2.3 to $9.6 \mathrm{GHz}$ respectively. Fig. 5a, Fig. 5c and Fig. 5d show the return loss graphs for switching configurations $\mathrm{C}_{1}, \mathrm{C}_{2}, \mathrm{C}_{5}, \mathrm{C}_{6}, \mathrm{C}_{7}$ and $\mathrm{C}_{8}$. The pattern reconfiguration is observed when the proposed antenna is reconfigured in $\mathrm{C}_{3}, \mathrm{C}_{4}$ configuration modes which is shown in Fig. $5 b$.

(C) Pandurangaiah Y., Satyanarayana R. V. S., 2020 DOI 10.15588/1607-3274-2020-1-3
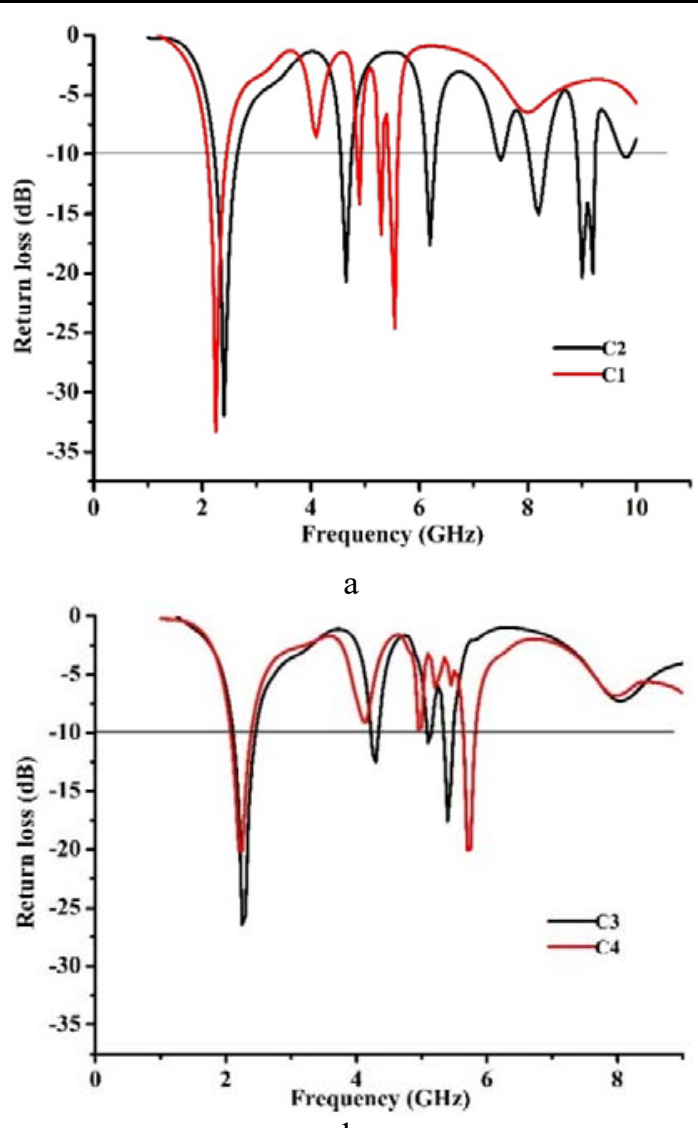

b
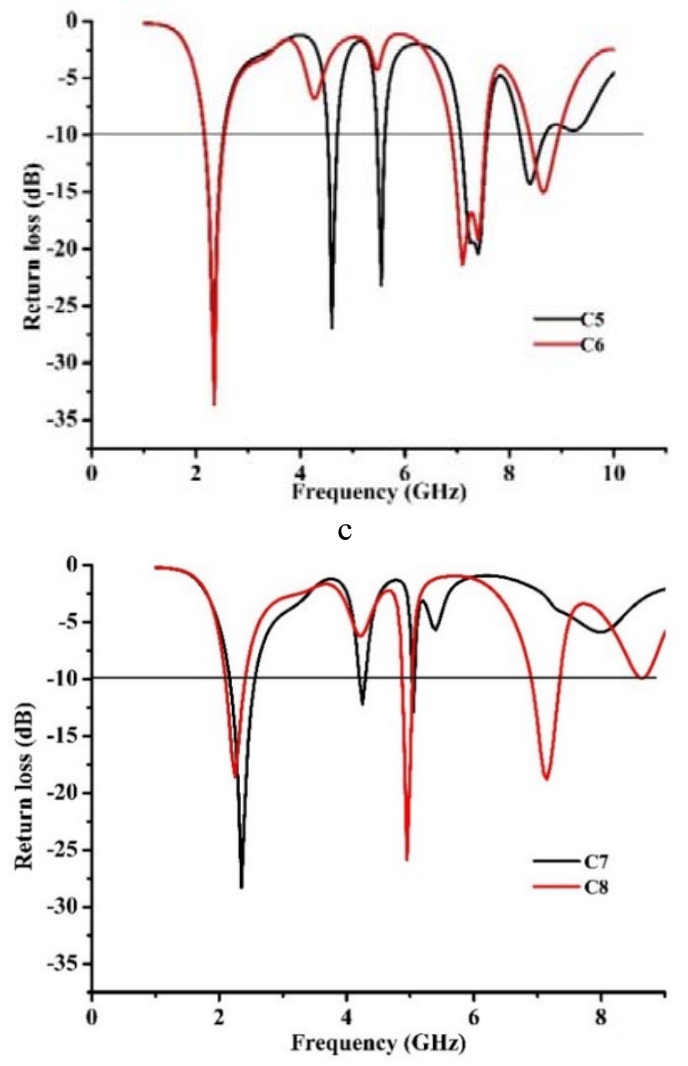

d

Figure 5 - Return Loss graphs of the proposed multi band reconfigurable antenna operating in all configurations: $\mathrm{a}-\mathrm{C}_{1}, \mathrm{C}_{2}$; $\mathrm{b}-\mathrm{C}_{3}, \mathrm{C}_{4} ; \mathrm{c}-\mathrm{C}_{5}, \mathrm{C}_{6} ; \mathrm{d}-\mathrm{C}_{7}, \mathrm{C}_{8}$ 


\section{EXPERIMENTS AND RESULTS}

The prototype of the proposed reconfigurable antenna is fabricated on a low cost FR4 substrate with dielectric constant 4.4 and thickness $1.6 \mathrm{~mm}$ and tested in order to validate the above simulated results. The photograph of the prototype antenna used for the measurement is shown in Fig. 6. The proposed antenna is configured in all operating modes using PIN diodes as mentioned in Section 3. All the return loss measurements were taken using $R \& S$ ZVA24 Vector Network Analyzer which operates in the range $10 \mathrm{MHz}-24 \mathrm{GHz}$. The simulated and measured reflection coefficients $S_{11}$ of the proposed reconfigurable antenna for all the operating modes are shown in Fig. 7. The quantitative values of the measured results are tabulated in Table 4. The measured results agree with simulated results with small variations in the resonant frequencies. These minimum variations of about $0.02 \%$ is observed at $4.3 \mathrm{GHz}$ in case 3 and maximum deviation of about $5.1 \%$ is obtained in case 4 at $2.3 \mathrm{GHz}$ frequency.

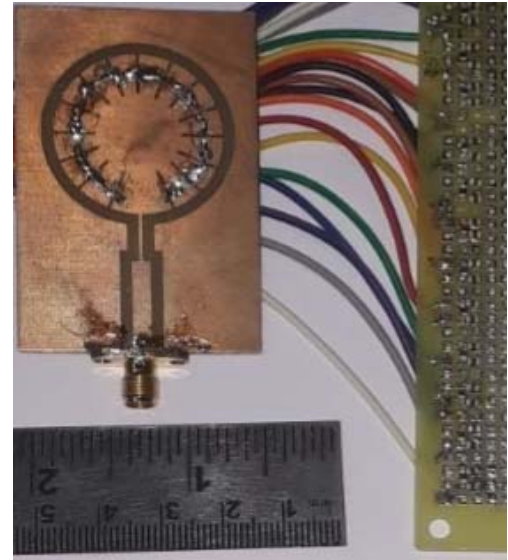

Figure 6 - Developed prototype of the proposed multi-band reconfigurable antenna

The radiation pattern measurements have been carried out in the anechoic chamber. The model of the measurement facility is given in Fig. 8. The measured radiation patterns in azimuth (xy-plane $\theta=0^{\circ} ; \theta=90^{\circ}$ ) and elevation (xz- plane $\varphi=0^{0} ;$ yz- plane $\varphi=90^{\circ}$ ) cuts for different operating modes are shown in Table 3 .

Table 4 summarize the corresponding measured frequency band of resonant frequency at all switching configurations. The simulated returns loss for all the switching configurations are below $-10 \mathrm{~dB}$. The obtained maximum gain at these resonant frequencies is also tabulated for each antenna configuration.

A highest bandwidth of $660 \mathrm{MHz}$ is obtained with resonant frequency of $7.1 \mathrm{GHz}$ when the antenna is operated with PIN diode configuration $\mathrm{C}_{6}$. The narrowband functionality of the proposed antenna offers virtual antenna size reduction. Further it is observed that the proposed frequency reconfigurable antenna can be used for S- \& Cband based Wi-Fi and WiMAX applications.

Each band of the proposed antenna when operated in different configurations with acceptable gain (gain $>2 \mathrm{~dB}$ ) can be used in several wireless applications like IEEE 802.16 WiMAX $2.3 \mathrm{GHz}(2.3-2.4 \mathrm{GHz})$, IEEE $802.11 \mathrm{~b} / \mathrm{g} \mathrm{Wi}-\mathrm{Fi}$
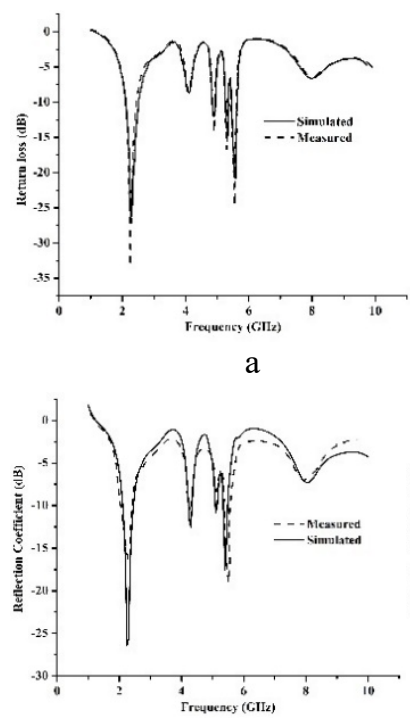

C

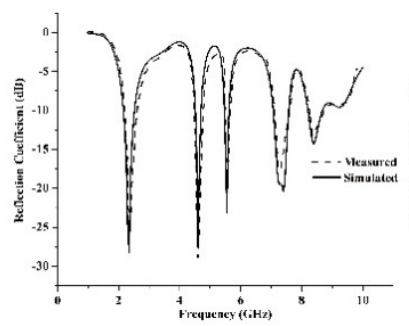

e

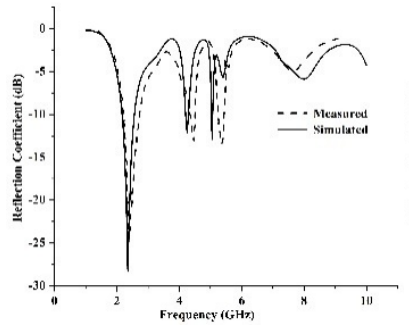

g

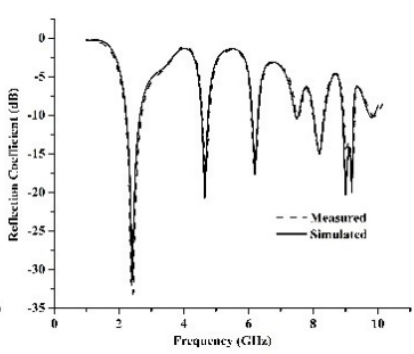

b

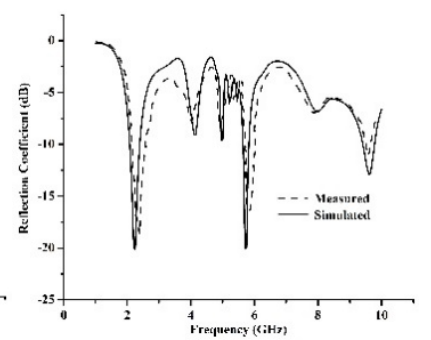

d

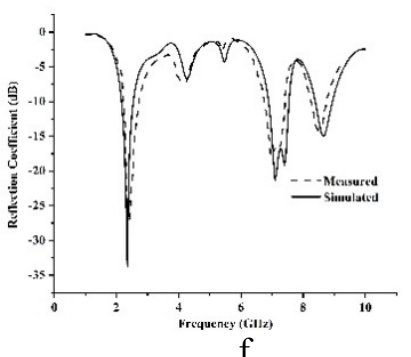

$\mathrm{f}$

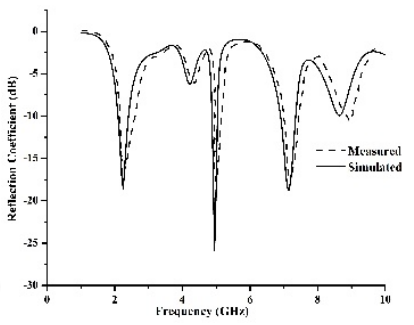

$\mathrm{h}$

Figure 7 - Measured and Simulated Return Loss operating in all configurations: $\mathrm{a}-\mathrm{C}_{1} ; \mathrm{b}-\mathrm{C}_{2} ; \mathrm{c}-\mathrm{C}_{3} ; \mathrm{d}-\mathrm{C}_{4} ; \mathrm{e}-\mathrm{C}_{5} ; \mathrm{f}-\mathrm{C}_{6} ; \mathrm{g}-$ $\mathrm{C}_{7} ; \mathrm{h}-\mathrm{C}_{8}$

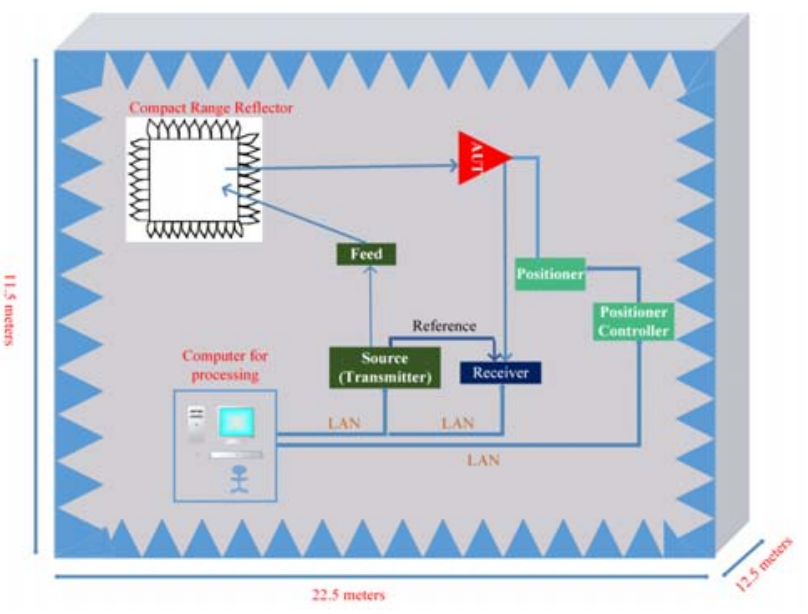

Figure 8 - Set up for measuring the Radiation Patterns 
$2.4 \mathrm{GHz} \quad(2.4-2.485 \mathrm{GHz})$ in S-band, WLAN $(5.1-$ $5.8 \mathrm{GHz})$, IEEE $802.11 \mathrm{a} \mathrm{Wi}-\mathrm{Fi}(5.72-5.87 \mathrm{GHz})$ in $\mathrm{C}$ band. Such applications for each configuration are listed in Table 3. The measured peak gain graph when operated in $\mathrm{C}_{2}, \mathrm{C}_{5}$ and $\mathrm{C}_{8}$ configurations is shown in Fig. 9. The gains are measured across the tuning range. The gain for the configuration $\mathrm{C}_{7}$ at $2.4 \mathrm{GHz}$ is higher than other operating modes is observed which is around $12 \mathrm{~dB}$ due to directional radiation pattern compared to other operating states which have almost dipole like omnidirectional pattern.

Table 3 - Elevation and Azimuth radiation patterns in two principle cuts operating in all modes

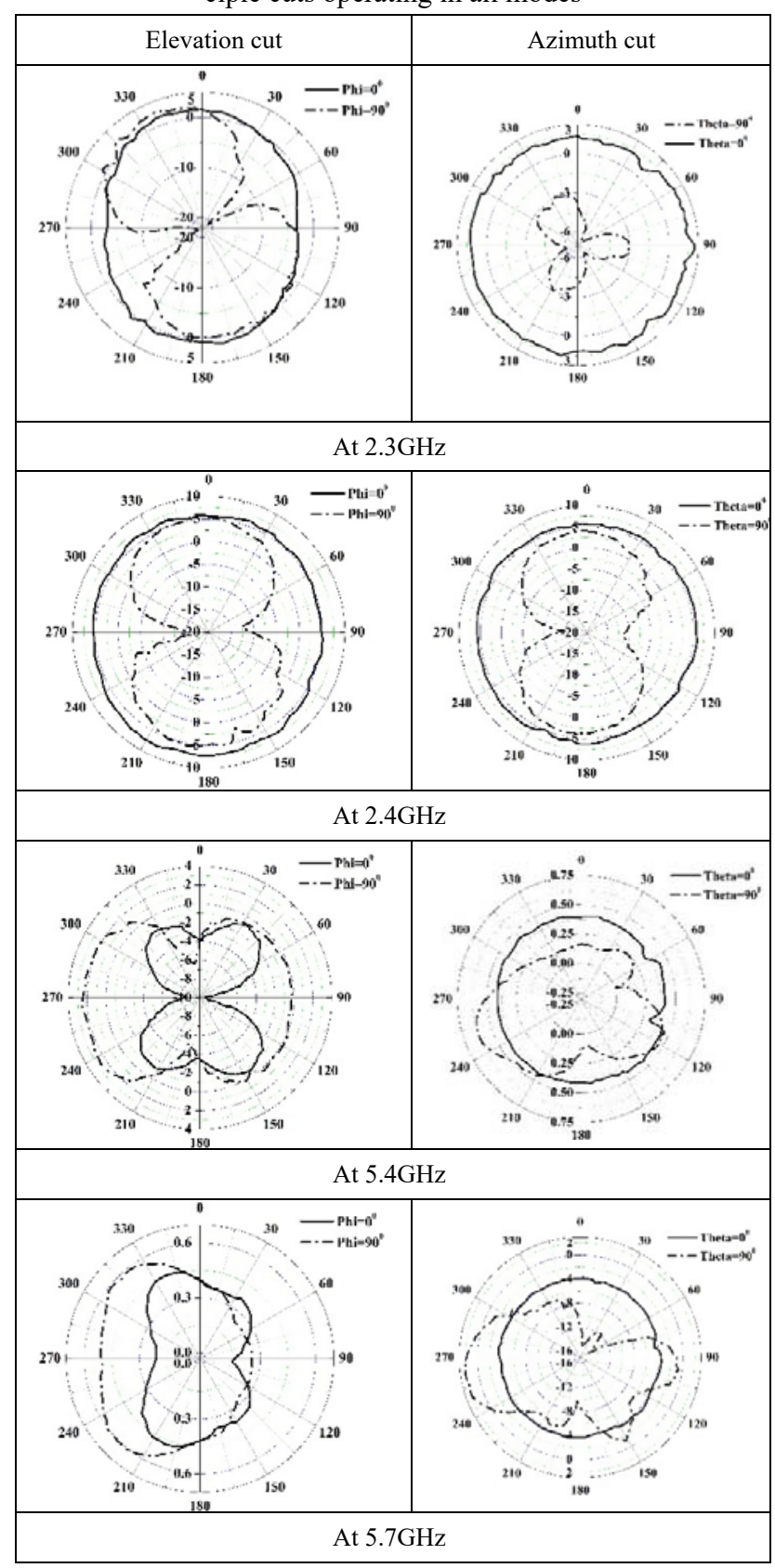

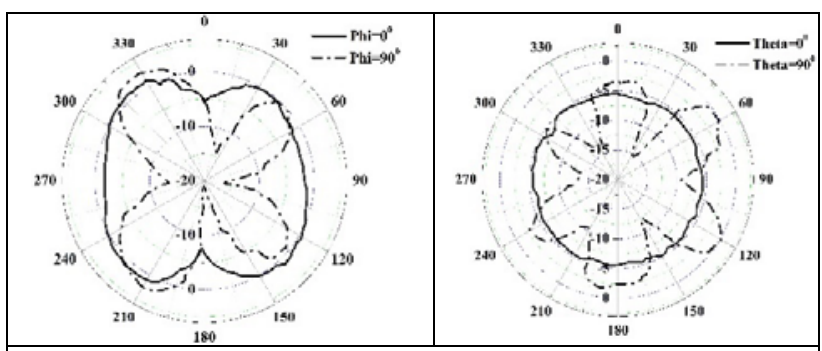

\begin{tabular}{|c|c|}
180 \\
\hline
\end{tabular}
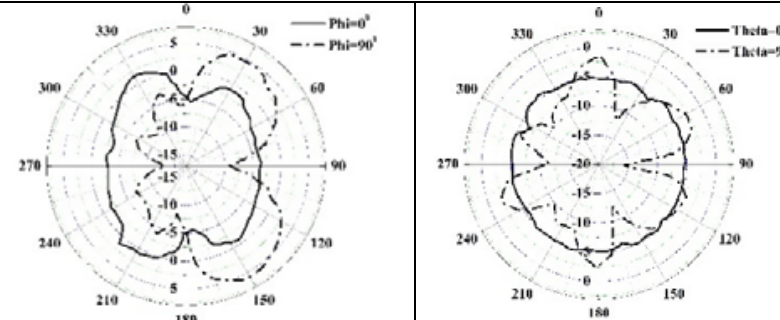

At $7.2 \mathrm{GHz}$
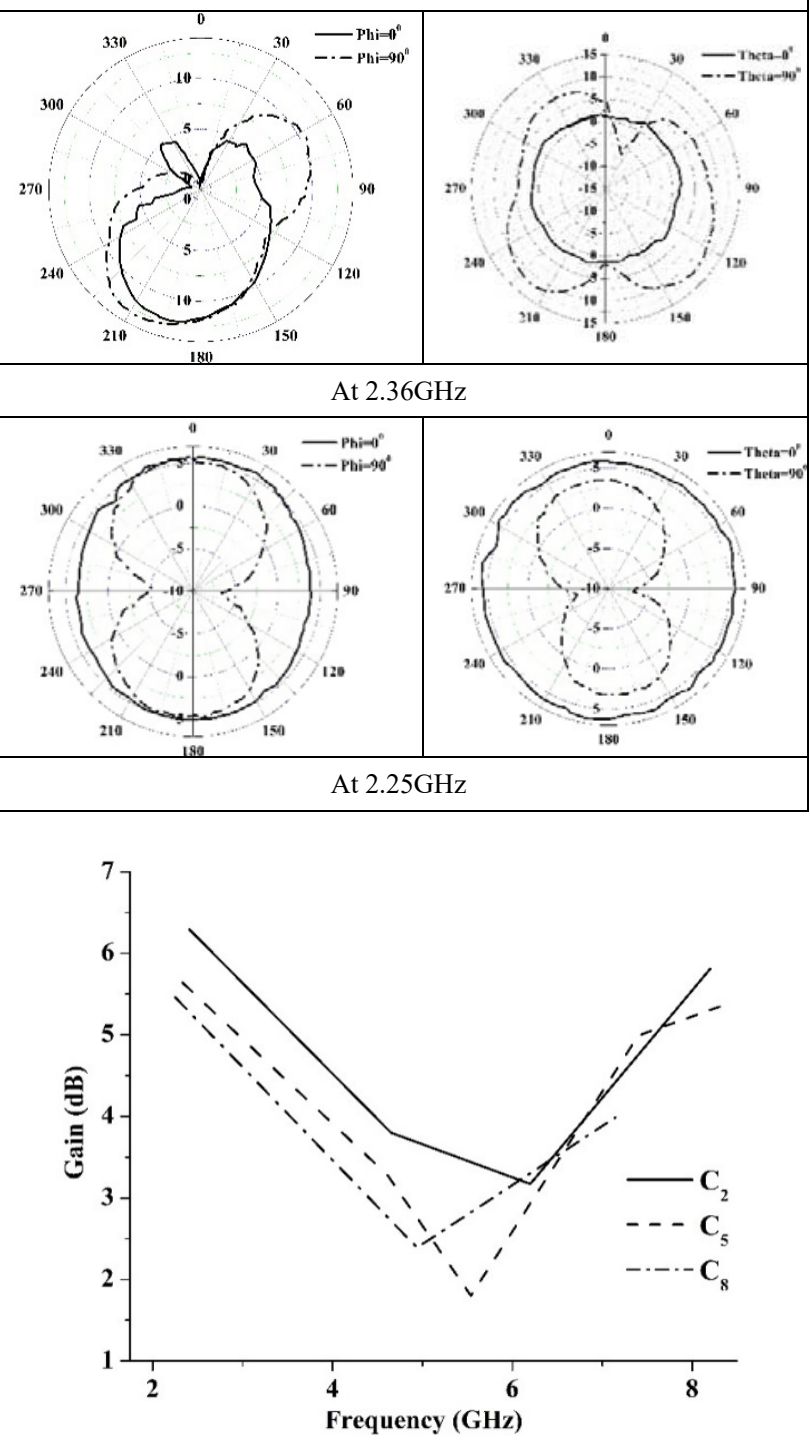

Figure 9 - Measured Peak Gain of the reconfigurable antenna operated in $\mathrm{C}_{2}, \mathrm{C}_{5}$ and $\mathrm{C}_{8}$ 
Table 4 - Operating frequencies and bands of the proposed Reconfigurable Antenna in each configuration

\begin{tabular}{|c|c|c|c|c|c|}
\hline Case & $\begin{array}{l}\text { Operating } \\
\text { Fre- } \\
\text { quency } \\
(\mathrm{GHz})\end{array}$ & $\begin{array}{c}\text { Return } \\
\text { Loss } \\
(\mathrm{dB})\end{array}$ & $\begin{array}{l}\text { Operat- } \\
\text { ing band } \\
(\mathrm{MHz})\end{array}$ & $\begin{array}{c}\text { Gain } \\
(\mathrm{dB}) \\
(\mathrm{xz}- \\
\text { plane })\end{array}$ & $\begin{array}{l}\text { Applica- } \\
\text { tion }\end{array}$ \\
\hline \multirow{4}{*}{$\mathrm{C}_{1}$} & 2.3 & 33.27 & 340 & 2.2 & $\begin{array}{c}\text { S-band } \\
\text { WiMAX }\end{array}$ \\
\hline & 4.9 & 14.17 & 70 & -1.1 & - \\
\hline & 5.3 & 16.75 & 70 & -6.1 & WLAN \\
\hline & 5.6 & 24.59 & 160 & -7.0 & WLAN \\
\hline \multirow{5}{*}{$\mathrm{C}_{2}$} & 2.4 & 31.93 & 420 & 6.3 & $\begin{array}{l}\text { S-band } \\
\text { Wi-Fi }\end{array}$ \\
\hline & 4.7 & 20.67 & 200 & 3.8 & C-band \\
\hline & 6.2 & 17.63 & 170 & 3.2 & C-band \\
\hline & 8.2 & 15.04 & 320 & 5.8 & X-band \\
\hline & 9.0 & 20.35 & 330 & 1.4 & X-band \\
\hline \multirow{3}{*}{$\mathrm{C}_{3}$} & 2.3 & 26.41 & 350 & 4.2 & WiMAX \\
\hline & 4.3 & 12.52 & 120 & -2.2 & - \\
\hline & 5.4 & 17.56 & 140 & 3.2 & WLAN \\
\hline \multirow[b]{2}{*}{$\mathrm{C}_{4}$} & 2.2 & 20.13 & 310 & 2.3 & S-band \\
\hline & 5.7 & 20.07 & 180 & 2.3 & $\begin{array}{c}\text { C-band } \\
\text { Wi-Fi }\end{array}$ \\
\hline \multirow{5}{*}{$\mathrm{C}_{5}$} & 2.3 & 28.21 & 350 & 5.6 & $\begin{array}{c}\text { S-band } \\
\text { WiMAX }\end{array}$ \\
\hline & 4.6 & 26.93 & 180 & 3.3 & C-band \\
\hline & 5.5 & 23.17 & 140 & 1.8 & - \\
\hline & 7.4 & 20.41 & 500 & 4.9 & C-band \\
\hline & 8.4 & 14.31 & 490 & 5.4 & X-band \\
\hline \multirow[t]{2}{*}{$\mathrm{C}_{6}$} & 2.3 & 33.71 & 380 & 5.3 & $\begin{array}{c}\text { S-band } \\
\text { WiMAX }\end{array}$ \\
\hline & 7.1 & 21.41 & 660 & 3.4 & C-band \\
\hline $\mathrm{C}_{7}$ & 2.36 & 28.34 & 390 & 12.9 & $\begin{array}{c}\text { S-band } \\
\text { WiMAX }\end{array}$ \\
\hline \multirow{3}{*}{$\mathrm{C}_{8}$} & 2.25 & 18.61 & 310 & 5.46 & $\begin{array}{c}\text { S-band } \\
\text { WiMAX }\end{array}$ \\
\hline & 4.94 & 25.86 & 150 & 2.39 & C-band \\
\hline & 7.15 & 18.79 & 450 & 3.99 & C-band \\
\hline
\end{tabular}

\section{CONCLUSIONS}

This paper presents a multi-band frequency- and pattern-reconfigurable circular patch antenna using coplanar waveguide feeding. The multi-band operation is achieved by using rectangular slots at edges of the circular patch at an interval of $22.5^{\circ}$ each. The reconfigurability in frequency can be obtained by suitably changing the electrical lengths of the patch using 15 RF PIN diode switches that are placed between the slots and operate in various configuration modes. The direction of the pattern is changed by changing the current distribution of the patch which is achieved by carefully selecting the appropriate switches. The antenna operates at different resonant modes in different configurations. Mostly it is operated at $2.3 \mathrm{GHz}$, $4.9 \mathrm{GHz}, 5.3 \mathrm{GHz}, 5.55 \mathrm{GHz}, 6.2 \mathrm{GHz}, 7.2 \mathrm{GHz}, 8.2 \mathrm{GHz}$ frequencies in various operating modes. The practical significance of measured results demonstrate that the antenna can be operated for suitable applications in S-band WiMAX, Wi-Fi and C- band Wi-Fi, WLAN with acceptable gain and good radiation performance.

Prospects for further research is to obtain fully compound reconfigurability that includes polarization diversity.

\section{REFERENCES}

1. Bernhard J. T. Reconfigurable Antennas. San Rafael, Morgan \& Claypool, 2007, $74 \quad$ p. DOI:10.2200/S00067ED1V01Y200707ANT004

2. Pandit S., Mohan A., Ray P. Compact FrequencyReconfigurable MIMO Antenna for Microwave Sensing Applications in WLAN and WiMAX Frequency Bands, IEEE Sensors Letters, 2018, Vol. 2, No. 2, pp. 1-4. DOI: 10.1109/LSENS.2018.2822598.

3. Wong H., Lin W., Huitema L., Arnaud E. Multi-Polarization Reconfigurable Antenna for Wireless Biomedical System, IEEE Transactions on Biomedical Circuits and Systems, 2017, Vol. 11, No. 3, pp. 652-660. DOI: 10.1109/TBCAS.2016.2636872.

4. Lin W., Wong H., Ziolkowski R. W. Wideband PatternReconfigurable Antenna with Switchable Broadside and Conical Beams, IEEE Antennas and Wireless Propagation Letters, 2017, Vol. 16, pp. 2638-2641. DOI: 10.1109/LAWP.2017.2738101.

5. Li H., Zhou Y., Mou X., Ji Z., Yu H., Wang L. Miniature Four-Band CPW-Fed Antenna for RFID/WiMAX/WLAN Applications, IEEE Antennas and Wireless Propagation Letters, 2014, Vol. 13, pp. 1684-1688. DOI: 10.1109/LAWP.2014.2345564.

6. Bartwal P., Gautam A. K., Singh A. K., Kanaujia B. K., Rambabu K. Design of compact multi-band meander-line antenna for global positioning system/wireless local area network/worldwide interoperability for microwave access band applications in laptops/tablets, IET Microwaves, Antennas \& Propagation, 2016, Vol. 10, No. 15, pp. 16181624. DOI: 10.1049/iet-map.2015.0777.

7. Zainarry S. N. M., Nguyen-Trong N., Fumeaux C. A Frequency and Pattern-Reconfigurable Two-Element Array Antenna, IEEE Antennas and Wireless Propagation Letters, 2018, Vol. 17, No. 4, pp. 617-620. DOI: 10.1109/LAWP.2018.2806355.

8. [Panneer Selvam Y., Gulam Nabi Alsath M., Kanagasabai M., Elumalai L., Kumar Palaniswamy S., Subbaraj S., Kingsly S., Konganathan G., Kulandhaisamy Indhumathi A Patch-Slot Antenna Array with Compound Reconfiguration, IEEE Antennas and Wireless Propagation Letters, 2018, Vol. 17, No. 3, pp. 525-528. DOI: 10.1109/LAWP.2018.2801124.

9. Chen S. L., Qin P. Y., Lin W., Guo Y. J. PatternReconfigurable Antenna with Five Switchable Beams in Elevation Plane, IEEE Antennas and Wireless Propagation Letters, 2018, Vol. 17, No. 3, pp. 454-457. DOI: 10.1109/LAWP.2018.2794990.

10. Nguyen-Trong N., Hall L., Fumeaux C. A frequency and pattern reconfigurable center-shorted microstrip antenna, IEEE Antennas and Wireless Propagation Letters, 2016, Vol. 15, pp. 454-457. DOI: 10.1109/LAWP.2016.2544943.

11. Lin W., Wong H., Ziolkowski R. W. Wideband pattern reconfigurable antenna with switchable broadside and conical beams, IEEE Antennas and Wireless Propagation Letters, 2016, Vol. 15, pp. 454-457. DOI: 10.1109/LAWP.2017.2738101.

12. Romputtal A., Phongcharoenpanich C. Frequency reconfigurable multiband antenna with embedded biasing network, IET Microwaves, Antennas \& Propagation, 2017, Vol. 11, No. 10, pp. 1369-1378. DOI: 10.1049/ietmap.2016.0648.

13. Yasir I. Abdulraheem. Design of frequency reconfigurable multiband compact antenna using two PIN diodes for WLAN/WiMAX applications, IET Microwaves, Antennas \& 
Propagation, 2017, Vol. 11, No. 8, pp. 1098-1105. DOI: 10.1049/iet-map.2016.0814.

14. Valizade Shahmirzadi N., Oraizi H. Design of reconfigurable coplanar waveguide-fed planar antenna for multiband multi-input-multi-output applications, IET Microwaves, Antennas \& Propagation, 2016, Vol. 10, No. 14, pp. 15911597. DOI: 10.1049/iet-map.2016.0316.

15. Fakharian M., Rezaei P., Orouji A. Reconfigurable Multiband Extended U-Slot Antenna with Switchable Polarization for Wireless Applications, IEEE Antennas and Propagation Magazine, 2015, Vol. 57, No. 2, pp. 194-202. DOI: 10.1109/MAP.2015.2414665.
16. Sedghara A., Atlasbaf Z. A novel single-feed reconfigurable antenna for polarization and frequency diversity, International Journal of Microwave and Wireless Technologies. 2017, Vol. 9, No. 5, pp. 1155-1161. DOI: $10.1017 / \mathrm{S} 1759078716001240$.

17. Balanis C. A. Antenna Theory Analysis and Design. Hoboken, John Wiley, 2005, 1136 p.

18. Simons R. N. Coplanar Waveguide circuits, Components and systems. New York, J. Wiley \& Sons, 2001, 464 p. DOI: $10.1002 / 0471224758$

Received 28.05.2019. Accepted 20.01.2020.

\section{УДК 621.3}

\section{МНОГОДИАПАЗОННАЯ АНТЕННА КРУГЛОЙ ФОРМЫ, ПОЛУКОМПОНЕНТНО РЕКОНФИГУРИРУЕМАЯ С ПОМОЩЬЮ РІN ДИОДОВ, С ЧАСТОТНЫМ И ПРОСТРАНСТВЕННЫМ МНОГООБРАЗИЕМ ДЛЯ БЕСПРОВОДНЫХ ПРИМЕНЕНИЙ}

Пандурангайя Й. - профессор, заведующий кафедрой электроники и средств связи, инженерный колледж Вардаман, Хайдарабад, Телангана, Индия.

Сатьянараяна Р.В.С. - доктор, профессор кафедры электроники и средств связи, Университет Шри Венкатешвара, Тирупати, Индия.

\section{АННОТАЩИЯ}

Актуальность. Решается проблема достижения многополосности с двумя или больше возможностями реконфигурации с использованием одной антенны для разнообразного использования в беспроводной связи. Заданием работы является моделирование прототипа объединяющего вышеуказанную функциональность.

Цель. Основная цель работы - создать очень эффективную и компактную антенну, удовлетворяющую всем требованиям при беспроводном применении, сочетающую возможность полукомпонентной реконфигурации и многополосность для использования в беспроводной связи.

Метод. В статье сообщается о разработке и исследовании частотных свойств и круговой диаграммы направленности плоской многоканальной реконфигурируемой антенны с использованием PIN-диодов. Она состоит из семи PIN-диодов, симметрично расположенных на каждой половине круга, разделенного продольной осью. Путем изменения управляемого переключения слотов, размещенных на круглом диске, которое осуществляется с помощью копланарного волновода, достигается необходимый механизм реконфигурации. Антенна может работать в 8 различных режимах с помощью 15 PINдиодов. Трансформация формы луча достигается за счет работы антенны во всех режимах. Основная антенна представляет собой круглый диск без слотов и предназначена для работы на частоте 2,4 ГГц. Трансформация частоты достигается путем изменения общей электрической длины слота путем активации переключателей в соответствующих положениях в различных режимах работы. Трансформация схемы достигается путем сохранения одинаковой общей электрической длины в каждом рабочем режиме путем изменения положения переключателей, ориентированных в определенном направлении в каждой половине круга.

Результаты. Была разработана модель и проведено экспериментальное моделирование с использованием Ansys HFSS.

Выводы. Предлагаемая антенна настроена на три частоты: 2,2 ГГц, 4,98 ГГц и 5,72 ГГц при работе в режиме изменения формы диаграммы направленности. Одновременное изменение частоты вместе с формой достигается с большим (на 6,2 ГГц, 8,2 ГГц и 9 ГГц) или меньшим количеством новых полос частот (на 7,1 ГГц), чем в режиме преобразования формы.

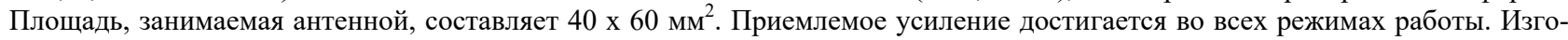
товлен прототип разработанной антенны, результаты моделирования подтверждены экспериментально.

КЛЮЧЕВЫЕ СЛОВА: частотное разнесение, разнесение по шаблонам, реконфигурируемые антенны, PIN-диоды, круговая диаграмма, радиочастотный переключатель, усиление.

\section{УДК 621.3 \\ БАГАТОДІАПАЗОННА АНТЕНА КРУГЛОЇ ФОРМИ, НАПІВКОМПОНЕНТНО РЕКОНФІГУРОВАНА ЗА ДОПОМОГОЮ РІN ДІОДІВ, 3 ЧАСТОТНИМ І ПРОСТОРОВИМ РІЗНОМАНІТТЯМ ДЛЯ БЕЗДРОТОВИХ ЗАСТОСУВАНЬ}

Пандурангайя Й. - професор, завідувач кафедри електроніки і засобів зв'язку, Інженерний коледж Вардаман, Хайдарабад, Телангана, Індія.

Сатьянараяна Р. В. С. - доктор, професор кафедри електроніки і засобів зв'язку, Університет Шрі Венкатешвара, Тірупаті, Індія.

\section{АНОТАЦІЯ}

Актуальність. Проблема досягнення багатосмужної функціональності і двох або більше можливостей реконфігурації 3 використанням єдиної антени для різноманітних застосувань бездротового зв'язку. Завданням роботи є моделювання прототипу, який поєднує в собі вищевказані функції.

Мета. Основна мета роботи - створити дуже ефективну і компактну антену, що задовольняє всім вимогам для бездротових застосувань, що поєднує напівкомпонентну реконфігурованість і багатосмужну функціональність для застосувань бездротового зв'язку. 
Метод. Антена може працювати в 8 різних режимах за допомогою 15 PIN-діодів. Трансформація форми променя досягається за рахунок роботи антени у всіх режимах. Основна антена являє собою круглий диск без слотів і призначена для роботи на частоті 2,4 ГГц. Трансформація частоти досягається шляхом зміни загальної електричної довжини слота шляхом активації перемикачів у відповідних положеннях в різних режимах роботи. Трансформація схеми досягається шляхом збереження однакової загальної електричної довжини в кожному робочому режимі шляхом зміни положення перемикачів, орієнтованих в певному напрямку в кожній половині кола. Антена може працювати в 8 різних режимах за допомогою 15 PIN-діодів. Трансформація форми променя досягається за рахунок роботи антени у всіх режимах. Основна антена являє собою круглий диск без слотів і призначена для роботи на частоті 2,4 ГГц. Трансформація частоти досягається шляхом зміни загальної електричної довжини слота шляхом активації перемикачів у відповідних положеннях в різних режимах роботи. Трансформація схеми досягається шляхом збереження однакової загальної електричної довжини в кожному робочому режимі шляхом зміни положення перемикачів, орієнтованих в певному напрямку в кожній половині кола.

Результати. Було розроблено модель і проведено експериментальне моделювання з використанням Ansys HFSS.

Висновки. Пропонована антена налаштована на три частоти: 2,2 ГГц, 4,98 ГГц і 5,72 ГГц при роботі в режимі зміни форми діаграми спрямованості. Одночасна зміна частоти разом з формою досягається з великою (на 6,2 ГГц, 8,2 ГГц і 9 ГГц) або меншою кількістю нових смуг частот (на 7,1 ГГц), ніж в режимі перетворення форми. Площа, яку займає антена, стано-

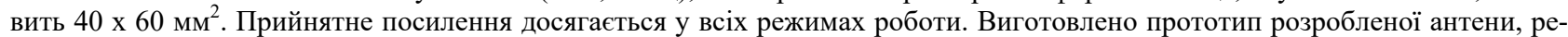
зультати моделювання підтверджуються експериментально.

КЛЮЧОВІ СЛОВА: частотне рознесення, діаграма спрямованості, реконфігуровані антени, PIN-діоди, кругова діаграма, радіочастотний перемикач, посилення.

\section{ЛІТЕРАТУРА / ЛИТЕРАТУРА}

1. Bernhard J. T. Reconfigurable Antennas / J. T. Bernhard. San Rafael: Morgan \& Claypool, 2007. - 74 p. DOI:10.2200/S00067ED1V01Y200707ANT004

2. Pandit S. Compact Frequency-Reconfigurable MIMO Antenna for Microwave Sensing Applications in WLAN and WiMAX Frequency Bands / S. Pandit, A. Mohan, P. Ray // IEEE Sensors Letters. - 2018. - Vol. 2, № 2 - P. 1-4. DOI: 10.1109/LSENS.2018.2822598.

3. Multi-Polarization Reconfigurable Antenna for Wireless Biomedical System / [H. Wong, W. Lin, L. Huitema E. Arnaud] // IEEE Transactions on Biomedical Circuits and Systems. - 2017. - Vol. 11, № 3. - P. 652-660. DOI: 10.1109/TBCAS.2016.2636872.

4. Lin W. Wideband Pattern-Reconfigurable Antenna with Switchable Broadside and Conical Beams / W. Lin, H. Wong, R. W. Ziolkowski // IEEE Antennas and Wireless Propagation Letters. - 2017. - Vol. 16. - P. 2638-2641. DOI: 10.1109/LAWP.2017.2738101.

5. Miniature Four-Band CPW-Fed Antenna for RFID/WiMAX/WLAN Applications / [H. Li, Y. Zhou, $X$. Mou et al.] // IEEE Antennas and Wireless Propagation Letters. - 2014. - Vol. 13. - P. 1684-1688. DOI: 10.1109/LAWP.2014.2345564.

6. Bartwal P. Design of compact multi-band meander-line antenna for global positioning system/wireless local area network/worldwide interoperability for microwave access band applications in laptops/tablets / [P. Bartwal, A. K. Gautam, A. K. Singh et al.] // IET Microwaves, Antennas \& Propagation. - 2016. - Vol. 10, № 15. - P. 1618-1624. DOI: 10.1049/iet-map.2015.0777.

7. Zainarry S. N. M. A Frequency- and Pattern-Reconfigurable Two-Element Array Antenna / S. N. M. Zainarry, N. Nguyen-Trong, C. Fumeaux // IEEE Antennas and Wireless Propagation Letters. - 2018. - Vol. 17, № 4. - P. 617 620. DOI: 10.1109/LAWP.2018.2806355.

8. A Patch-Slot Antenna Array with Compound Reconfiguration / [Y. Panneer Selvam, M. Gulam Nabi Alsath, M. Kanagasabai et al.] // IEEE Antennas and Wireless Propagation Letters. - 2018. - Vol. 17, № 3. - P. 525-528. DOI: 10.1109/LAWP.2018.2801124.

9. Pattern-Reconfigurable Antenna with Five Switchable Beams in Elevation Plane / [S. L. Chen, P. Y. Qin, W. Lin, Y. J. Guo] // IEEE Antennas and Wireless Propagation Let- ters. - 2018. - Vol. 17, № 3. - P. 454-457. DOI: 10.1109/LAWP.2018.2794990.

10. Nguyen-Trong N. A frequency- and pattern reconfigurable center-shorted microstrip antenna / N. Nguyen-Trong, L. Hall, C. Fumeaux // IEEE Antennas and Wireless Propagation Letters. - 2016. - Vol. 15. - P. 454-457. DOI: 10.1109/LAWP.2016.2544943.

11. Lin W. Wideband pattern reconfigurable antenna with switchable broadside and conical beams / W. Lin, H. Wong, R. W. Ziolkowski // IEEE Antennas and Wireless Propagation Letters. - 2016. - Vol. 15. - P. 454-457. DOI: 10.1109/LAWP.2017.2738101.

12. Romputtal A. Frequency reconfigurable multiband antenna with embedded biasing network / A. Romputtal, C. Phongcharoenpanich // IET Microwaves, Antennas \& Propagation. - 2017. - Vol. 11, № 10. - P. 1369-1378. DOI: 10.1049/iet-map.2016.0648

13. Yasir I. Abdulraheem. Design of frequency reconfigurable multiband compact antenna using two PIN diodes for WLAN/WiMAX applications / I. Yasir // IET Microwaves, Antennas \& Propagation. - 2017. - Vol. 11, № 8. - P. 1098 1105. DOI: 10.1049/iet-map.2016.0814.

14. Valizade Shahmirzadi N. Design of reconfigurable coplanar waveguide-fed planar antenna for multiband multi-inputmulti-output applications / N. Valizade Shahmirzadi, H. Oraizi // IET Microwaves, Antennas \& Propagation. 2016. - Vol. 10, № 14. - P. 1591-1597. DOI: 10.1049/ietmap.2016.0316.

15. Fakharian M. Reconfigurable Multiband Extended U-Slot Antenna with Switchable Polarization for Wireless Applications / M. Fakharian, P. Rezaei, A. Orouji // IEEE Antennas and Propagation Magazine. - 2015. - Vol. 57, № 2. P. 194-202. DOI: 10.1109/MAP.2015.2414665.

16. Sedghara A. A novel single-feed reconfigurable antenna for polarization and frequency diversity / A. Sedghara, Z. Atlasbaf // International Journal of Microwave and Wireless Technologies. - 2017. - Vol. 9, № 5. - P. 1155-1161. DOI: $10.1017 / \mathrm{S} 1759078716001240$.

17. Balanis C. A. Antenna Theory Analysis and Design / C. A. Balanis. - Hoboken : John Wiley, 2005. - 1136 p.

18. Simons R.N. Coplanar Waveguide circuits, Components and systems / R.N. Simons. - New York : J. Wiley \& Sons, 2001. -464 p. DOI: $10.1002 / 0471224758$ 